\title{
Cyclophosphamide treatment evoked side effect on skeletal muscle actin, monitored by DSC
}

\author{
Péter Farkas $^{1}$ · Dávid Szatmári ${ }^{2}$. Franciska Könczöl ${ }^{3}$ · Dénes Lőrinczy²
}

Received: 4 January 2021 / Accepted: 15 March 2021 / Published online: 4 April 2021

(c) The Author(s) 2021

\begin{abstract}
Several kind of drugs—used in cancer treatments—-such as cyclophosphamide (CP) can also trigger a disease classified as toxic polyneuropathy. Polyneuropathy is a simultaneous malfunction of several peripheral nerves, typical side effect of a cancer therapy. In our previous study, we used CP treated in vitro animal model (Guinea pig) with a comparable dosage and time handling of human protocol to show evidences of this drug-induced effects. We could show a dose-dependent difference between in $T_{\mathrm{m}}$ and $\Delta H_{\text {cal }}$ of untreated and treated samples assigned to their intact muscle and nerve, blood plasma and red blood cells. In our current study we analyze this side effect on skeletal muscle actin (prepared from m. psoas of rabbit) by DSC (differential scanning calorimetry), to follow the possible consequence of drug treatment on the "activator" of muscle contraction. We have demonstrated that run of DSC curves, $T_{\mathrm{m}} \mathrm{s}$ together with the $\Delta H_{\text {cal }}$ exhibit clear CP effect. In case of $\mathrm{Ca}^{2+} \mathrm{G}$ actin it is manifested in a well separated second high denaturing temperature as a consequence of CP binding into the cleft. This way the nucleotide binding cleft with subdomains 1 and 3 becomes less flexible, indicating clear sensitivity to CP treatment. In F-actin samples, the main peak represents the thermal denaturation of subdomains 1 and 3, and the increased calorimetric enthalpy administrating $\mathrm{Ca}^{2+}$ as well as $\mathrm{CP}$ refers to a more rigid structure. These alterations can be the molecular background in the malfunction of muscle in case of polyneuropathy after CP treatment.
\end{abstract}

Keywords Polyneuropathy $\cdot$ Cyclophosphamide $\cdot \mathrm{Ca}^{2+} \cdot \mathrm{Mg}^{2+} \cdot \mathrm{G}$ and skeletal $\mathrm{F}$ actin $\cdot \mathrm{DSC}$

\section{Introduction}

In the medical practice cyclophosphamide (CP) is applied as an anticancer drug [1]. It has a lot of beneficial effects but as most of the different drugs has some unpleasant short and long term side effects as well [2-7]. Refers to a forensic medicine indication, we have checked its possible malfunction in an animal model using Guinea pig [7]. In case of both sides of peripheral nerve and $\mathrm{m}$. gastrocnemius [8], and in the left ventricle [9] as well as using the red blood cells and blood plasma coming from treated animals, we have observed dose-dependent damages during the thermal

Dénes Lőrinczy

denes.lorinczy@aok.pte.hu

1 Department of Medical Imaging, Medical School, University of Pécs, Szigeti Str. 12, Pécs 7624, Hungary

2 Department of Biophysics, Medical School, University of Pécs, Szigeti Str. 12, Pécs 7624, Hungary

3 Department of Forensic Medicine, Medical School, University of Pécs, Szigeti Str. 12, Pécs 7624, Hungary denaturation of these samples by DSC [10]. We could separate the effect of the drug in Guinea pig muscle samples for actin and myosin applying the deconvolution procedure in the DSC scans $[11,12]$ and using similar information collected from psoas muscle fibers [13, 14].

The actin is one of the main components of the cytoskeleton. It plays important roles during muscle contraction as a dynamic compound of actomyosin complex and in the motility of eukaryotic cells [15-21]. The actin can be found in monomeric, but in the muscle mainly in filamentous form. The actin monomer can bind a nucleotide in complex with divalent cations $\left(\mathrm{Ca}^{2+}\right.$ or $\left.\mathrm{Mg}^{2+}\right)$ in the cleft between the two main domains of the protein [22]. During actin polymerization, the ATP is hydrolyzed into ADP and $P_{i}[23-30]$. The ADP. $P_{i}$ state is transient as the inorganic phosphate product is released from actin after polymerization (resulting an ATP and ADP end of the filament). For the characterization of the short-lived ADP.P $P_{i}$ state nucleotide analogues such as ADP. $\mathrm{BeF}_{\mathrm{x}}$ or ADP.AlF $\mathrm{Al}_{4}$ can be applied, because the $\mathrm{P}_{\mathrm{i}}$ release is not reversible during the ATP hydrolysis cycle [31-33]. This way we can get the simulation of "weak" binding state, 
which has enough long life time for different spectroscopic and thermal investigation.

The effect of the binding of ligands to actin filaments is often cooperative, i.e., the binding of the ligand induces allosteric conformational changes in the actin protomers distant from the bound protomer [34-38]. In the past, we have studied the effect of different toxins-jaspakinoline and phalloidin-on actin prepared from rabbit skeletal muscle $[39,40]$. During the thermal denaturation of the treated actin, we have observed a toxin concentration dependent cooperative binding effect of toxins. It was realized that after these toxin treatments at least three actin populations can be identified: those which bound directly a toxin molecule (with highest denaturation temperature, $T_{\mathrm{m}}$ ), those which shows the effect of cooperative binding in the vicinity of those actin which has bound toxin (smaller $T_{\mathrm{m}}$ ), as well as toxin free actin which has "normal" denaturation temperature.

It was also shown by previous DSC data $[8,11,12]$ that muscle filament system was changed by the CP treatment. Using all the above-mentioned data, we have planned the recent investigation to look for a possible effect of $\mathrm{CP}$ on filamentous actin and actin monomers supposing that the chemo-therapeutic agent binding can cause similar effects in their structure as toxin binding.

\section{Materials and methods}

\section{Actin preparation from rabbit skeletal muscle}

$\mathrm{G}$ and $\mathrm{F}$-actin in $\mathrm{Ca}^{2+}$ and $\mathrm{Mg}^{2+}$ form was prepared from acetone powder of rabbit skeletal muscle as described earlier by Spudich and Watt [41] and stored in MOPS-buffer (2 mM MOPS, $0.2 \mathrm{mM}$ ATP, $0.1 \mathrm{mM} \mathrm{CaCl}_{2}, 0.1 \mathrm{mM}$ $\beta$-mercaptoethanol, $\mathrm{pH}$ 7.4). Actin concentration was determined from the absorption spectra (Jasco V-550 spectrophotometer) (as the average concentration by $\varepsilon=1.11 \mathrm{~mL} \mathrm{mg}^{-1}$ $\mathrm{cm}^{-1}$ at $280 \mathrm{~nm}$ and $\varepsilon=0.63 \mathrm{~mL} \mathrm{mg}^{-1} \mathrm{~cm}^{-1}$ at $290 \mathrm{~nm}$ ). We applied $2 \mathrm{mM}$ EGTA then $2 \mathrm{mM} \mathrm{MgCl}$ treatment for exchange calcium to magnesium on $2 \mathrm{mg} \mathrm{mL}^{-1}$ actin monomers. It was required to use actin in samples as concentrated as possible, but based on our experience the concentration of actin should be fixed at maximum $2 \mathrm{mg} \mathrm{mL}^{-1}$ because this concentration of monomers and filaments show stable thermodynamical equilibrum. High concentration of monomers can start spontaneous polymerization and high number of filaments can be in superstructural remodeling by their interfilamental interactions. Actin polymerization process was initialized by $100 \mathrm{mM} \mathrm{KCl}$ addition.

\section{Cyclophosphamide treatment}

For in vitro measurements, applied dosage of cyclophosphamide $(\mathrm{CP})$ is comparable to the human dosage (150 $\mathrm{mg} \mathrm{kg}^{-1}$ b.m.) [7-10]. The average actin content of skeletal muscle is roughly $10 \%$ [41] thus the average mass of Guinea pig gastrocnemius muscle (from our previous study [8]) divided by 10 then by the mass of CP passed in the muscle $\left(150 \mathrm{mg} \mathrm{kg}^{-1} * \frac{\text { massof gastrocnemius }}{\text { massofthehody }}\right)$ resulted that the actin to $\mathrm{CP}$ ratio has to be $\frac{2000}{3}$ (it means $2 \mathrm{mg}$ actin to $3 \mu \mathrm{g}$ $\mathrm{CP}$ ) as a single dose. However, as we used actin from rabbit skeletal muscle, we can assume that the distribution of $\mathrm{CP}$ in rabbit skeletal muscle should be the same as in Guinea pig skeletal muscle. We carried out experiments-to achieve a more pronounced effect-with 5 times dose of $\mathrm{CP}$ to treat actin followed by incubation at room temperature for $1 \mathrm{~h}$ (in case of model experiment the animal underwent to a real, long lasting chemotherapeutic protocol).

\section{DSC measurements}

The samples were freshly prepared before all measurements. The analysis was made by a SETARAM Micro-DSCII calorimeter between 0 and $100^{\circ} \mathrm{C}$ with heating rate of $0.3 \mathrm{~K} \mathrm{~min}^{-1}$. Conventional Hastelloy batch vessels $\left(\mathrm{V}_{\max }=1 \mathrm{~mL}\right)$ were used for the experiment to investigate denaturation with $950 \mu \mathrm{L}$ sample volume (sample + buffer) in average. Samples' masses were between 920 and 970 mgs. MOPS buffer was used as a reference. The reference and sample vessels were equilibrated with a precision of $\pm 0.1 \mathrm{mg}$; this way we did not need to do any correction between vessels' heat capacity. With the help of a two-point SETARAM peak integration setting, calorimetric enthalpy was calculated from the area under the heat absorption curve, and then, the results [denaturation or melting temperature $\left(T_{\mathrm{m}}\right)$ and calorimetric enthalpy $\left(\Delta H_{\text {cal }}\right)$ data of samples] were compared.

\section{Results}

Figure 1 shows our summarized denaturation results on different form of actin before and after $\mathrm{CP}$ treatment. The scans are average of three measurements. Statistical analysis was not performed because of the small number of observation. The main goal of measurements was to see the tendency of $\mathrm{CP}$ treatment on different form of actin to find explanation for our former study.

In case of thermal denaturation of biological samples, it is generally accepted that the difference of nearly $1{ }^{\circ} \mathrm{C}$ in $T_{\mathrm{m}}$ is a remarkable deviation. Because the usual instrument accuracy in the determination of calorimetric enthalpy in 
Fig. 1 Thermal denaturation curves of different $\mathrm{G}$ and $\mathrm{F}$-actin in the presence (solid gray line) and in the absence of CP (dotted line) (endotherm effect is deflected downward)
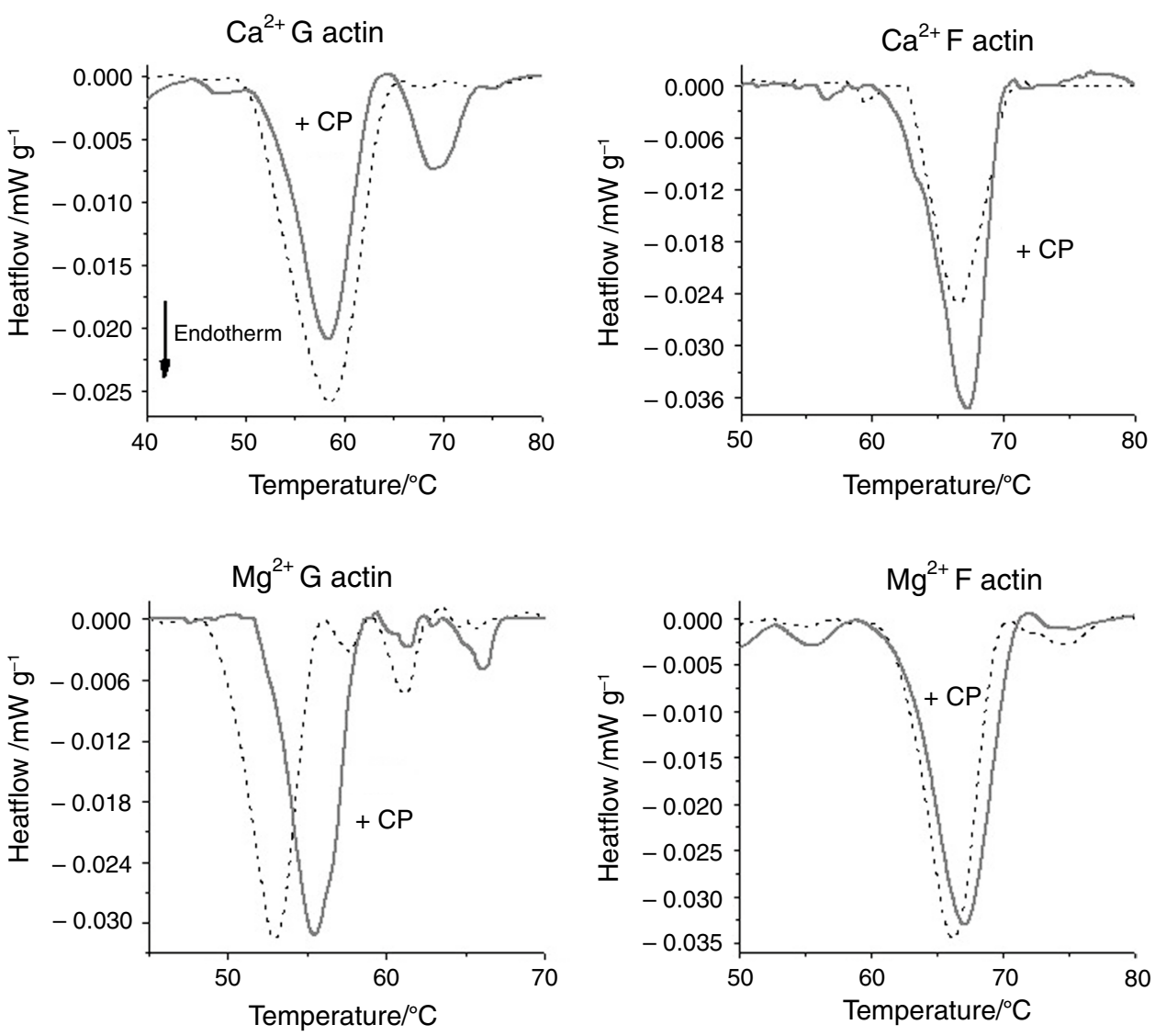

Table 1 Remarkable thermal parameters of the denaturation of different native and $\mathrm{CP}$ treated actin solutions

\begin{tabular}{|c|c|c|c|c|}
\hline & \multicolumn{2}{|l|}{$\mathrm{Ca}^{2+}$} & \multicolumn{2}{|l|}{$\mathrm{Mg}^{2+}$} \\
\hline & \multicolumn{4}{|c|}{ Thermal parameters } \\
\hline & $\overline{T_{\mathrm{m}} \rho \mathrm{C}}$ & $\Delta H_{\text {cal_total }} / \mathrm{Jg}^{-1}$ & $T_{\mathrm{m}} \rho \mathrm{C}$ & $\Delta H_{\text {cal_total }} / \mathrm{Jg}^{-1}$ \\
\hline \multicolumn{5}{|l|}{$G$-actin } \\
\hline Native & 57.89 & 0.041 & $\begin{array}{l}52.3 \\
61.2\end{array}$ & 0.037 \\
\hline $\mathrm{CP}$ treated & $\begin{array}{l}57.94 \\
69.42\end{array}$ & 0.042 & $\begin{array}{l}55.46 \\
66.03\end{array}$ & 0.038 \\
\hline \multicolumn{5}{|l|}{$F$-actin } \\
\hline Native & 66.52 & 0.044 & 65.9 & 0.039 \\
\hline $\mathrm{CP}$ treated & 66.82 & 0.05 & 66.8 & 0.041 \\
\hline
\end{tabular}

Data are averages of three different measurements. The calorimetric enthalpy refers for the whole denaturation range and normalized on the sample mass

case of commercial DSC has 5\% error, the deviations in this range are also negligible. In line with these information, we observed the following effects for the different actin samples (see Fig. 1 and Table 1):

Protocols of actin isolation and preparation from different laboratories show negligibly small differences which can have influence on the thermodynamical responses of actin. Actin concentration-dependent intermolecular forces and charges can modify the parameters of actin denaturation what we tried to avoid thus fixed it at $2 \mathrm{mg} \mathrm{mL}^{-1}$. As a result of them the main denaturation peaks for untreated $\mathrm{Ca}^{2+}-\mathrm{Mg}^{2+} \mathrm{G}$ and $\mathrm{F}$-actin are in a good agreement with former literature data [42-49]. After CP treatment in both G-actin plus endotherm peak appeared in the higher temperature range. It can prove- beside the structural data $[32,39$, $40,49,50]$ - that the nucleotide binding clefts between the two big domains of $\mathrm{G}$ actin underwent a structural change (became more rigid) as a consequence of $\mathrm{CP}$ binding. The calorimetric enthalpy in case of untreated $\mathrm{Mg}^{2+} \mathrm{G}$-actin was $10 \%$ smaller than in case of $\mathrm{Ca}^{2+} \mathrm{G}$ actin. To surprise, the CP treatment has only mild effect on $\Delta H_{\text {cal }}$ in the case of $\mathrm{Ca}^{2+} \mathrm{G}$ as well as $\mathrm{Mg}^{2+} \mathrm{G}$ actin.

In case of F-actins the main $T_{\mathrm{m}}$ was above $65^{\circ} \mathrm{C}$ which is higher than in case of G-actin as the consequence of the polymerization-based structural stabilization. After the $\mathrm{CP}$ treatment in case of $\mathrm{Ca}^{2+} \mathrm{F}$-actin the main denaturation peak was not changed remarkably, while the lower one decreased by $3{ }^{\circ} \mathrm{C}$ and a shoulder was appeared at $63{ }^{\circ} \mathrm{C}$. In the contrast with $\mathrm{Mg}^{2+} \mathrm{F}$-actin a lower peak was appeared at $55{ }^{\circ} \mathrm{C}$, the main one increased by $1{ }^{\circ} \mathrm{C}$ and the peak at $74{ }^{\circ} \mathrm{C}$ (together with the $55{ }^{\circ} \mathrm{C}$ ) practically does not give 
remarkable enthalpy contribution. The calorimetric enthalpy of $\mathrm{Ca}^{2+} \mathrm{F}$-actin was increased compared to G-actin, and the CP treatment increased it by $\sim 20 \%$. $\left(\mathrm{Mg}^{2+} \mathrm{F}\right.$-actin exhibited $\sim 5$ higher enthalpy change than in $\mathrm{G}$ form, and $\mathrm{CP}$ treatment increased it $\sim 5 \%$ too, unfortunately both are in the range of error of enthalpy determination.)

\section{Discussion}

The reason - of some differences between our recent denaturation temperatures compared to the literature data-can be the difference in the concentration of samples, in the heating rate as well as in the different measuring principle of our system (most of the devices use capillary sample holders why our is a big [V=1 $\mathrm{mL}]$ stainless steel cylinder. The instrument is a heat-flux calorimeter.). Run of DSC curves (see Fig. 1), and the denaturation temperatures (see Table 1) together with the calorimetric enthalpy exhibit the effect of CP treatment. In case of $\mathrm{Ca}^{2+} \mathrm{G}$ actin, it is manifested in a well separated second high denaturing temperature (see Fig. 1) as a consequence of less flexible side of nucleotide binding cleft with subdomains 1 and 3 [51], thus the actin monomers are sensitive to $\mathrm{CP}$ treatment, similarly as in case of $\mathrm{P}_{\mathrm{i}}$ analogues or toxins [39-49]. The $\mathrm{Mg}^{2+}-\mathrm{G}$-actin has smaller denaturation temperature because $\mathrm{Ca}^{2+}$ is a structure stabilizing agent. $\Delta H_{\text {cal }}$ well demonstrates this effect too (see Table 1). The increased $T_{\mathrm{m}}$ for $\mathrm{CP}$ treated $\mathrm{Mg}^{2+} \mathrm{G}$-actin proves also a more rigid state in the cleft compared with the native one.

In F-actin samples the higher denaturation temperature in both cases is the consequence of polymerization. The main peak represents the thermal denaturation of subdomains 1 and 3, while a pre-transition at $\sim 60{ }^{\circ} \mathrm{C}$ and $\sim 55 \mathrm{oC}$ in case of $\mathrm{Ca}^{2+}$ and $\mathrm{Mg}^{2+}$ F-actin, respectively, could be the contribution of a more flexible structure of nucleotide binding cleft (see Fig. 1). The $T_{\mathrm{m}}$ of $\mathrm{CP}$ treatment in $\mathrm{Ca}^{2+} \mathrm{F}$ actin shows a mild stabilization of structure, while in the presence of $\mathrm{Mg}^{2+}$ indicates a more remarkable strengthening $\left(\sim 1^{\circ} \mathrm{C}\right)$. The main $T_{\mathrm{m}}$ practically is not affected by CP treatment in case of $\mathrm{Ca}^{2+} \mathrm{F}$-actin, but the remarkable increase in $\Delta H_{\text {cal }}$ is a strong sign of the more rigid structure. F-actin with $\mathrm{Mg}^{2+}$ nucleotide showed an increased $T_{\mathrm{m}}$ and a mild $\Delta H_{\text {cal }}$ increase of the main denaturation as the sign of more rigid structure.

\section{Conclusions}

The name actin refers to its activator ability [52-54]. It means that the actual molecular dynamic capability of actin crucial way affects the actin-myosin interaction, so force generation during contraction. Referring to our forensic medical case of the polyneuropathic condition after CP treatment [7] as well as to the animal model experiments
[8-12] which motivated our present study, we can state that $\mathrm{CP}$ treatment can make such a structural change in muscle protein which can be manifested in burning and panging pain sensation in the limbs, muscle spasm, progressive distal weakness because of more rigid structure of actin [7]. These symptoms are typical signs of polyneuropathy. This way we can confirm the finding that toxic effects, such as industrial poisons $[39,40]$ and other pharmaceutical products play an important role in the occurrence of polyneuropathy [55].

Acknowledgements This work was supported by CO-272 (OTKA) grant (D.L.).

Authors' contributions Dr. Péter Farkas involved in sample collection and handling with cyclophosphamide and data analysis. Dr. Dávid Szatmári participated in sample preparation and handling, data analysis, manuscript writing. Dr. Franciska Könczöl involved in rising the problem, sample collection and handling with cyclophosphamide. Prof. Dr. Dénes Lôrinczy, corresponding author and principle investigator, involved in DSC experiments, data analysis and manuscript writing.

Funding Open access funding provided by University of Pécs.

Availability of data and materials There are no additional available data to upload.

\section{Declarations}

Competing interests The authors declare that they have no known competing financial interests or personal relationships that could have appeared to influence the work reported in this paper.

Ethics approval and consent to participate All procedures followed were approved and in accordance with the ethical standards of the responsible committee on animal experimentation (institutional and national) and with the revised Helsinki Declaration of 1975.

Consent for publication Copyright form has been uploaded with the manuscript.

Open Access This article is licensed under a Creative Commons Attribution 4.0 International License, which permits use, sharing, adaptation, distribution and reproduction in any medium or format, as long as you give appropriate credit to the original author(s) and the source, provide a link to the Creative Commons licence, and indicate if changes were made. The images or other third party material in this article are included in the article's Creative Commons licence, unless indicated otherwise in a credit line to the material. If material is not included in the article's Creative Commons licence and your intended use is not permitted by statutory regulation or exceeds the permitted use, you will need to obtain permission directly from the copyright holder. To view a copy of this licence, visit http://creativecommons.org/licenses/by/4.0/. 


\section{References}

1. WHO Model List of Essential Medicines (April 2015) http://www. who.int/selection_medicines/committees/expert/20/EML_2015_ FINAL_amended_JUN2015.pdf?ua $=1$

2. Notermans NC, Lokhorst HM, Franssen H, Van der Graaf Y, Teunissen LL, Jennekens FG, Van den Berg LH, Wokke JH. Intermittent cyclophosphamide and prednisone treatment of polyneuropathy associated with monoclonal gammopathy of undetermined significance. Neurology. 1996;47(5):1227-33.

3. Hamidou MA, Belizna C, Wiertlewsky S, Audrain M, Biron C, Grolleau JY. MussiniJM: Intravenous cyclophosphamide in refractory polyneuropathy associated with IgM monoclonal gammopathy: an uncontrolled open trial. Am J Med. 2005;118(4):426-30.

4. Kemp G, Rose P, Lurain J, Berman M, Manetta A, Roullet B, Homesley H, Belpomme D, Glick J. Amifostine pretreatment for protection against cyclophosphamide-induced and cisplatininduced toxicities: results of a randomized control trial in patients with advanced ovarian cancer. J Clin Oncol. 1996;14:2101-12.

5. Spitzer TR, Cirenza E, McAfee S, Foelber R, Zarzin J, Cahill R, Mazumder A. Phase I-II trial of high-dose cyclophosphamide, carboplatin and autologous bone marrow or peripheral blood stem cell rescue. Bone Marrow Transpl. 1995;15:537-42.

6. Tschöp K, Rommel F, Schmidkonz P, Emmerich B, Schulze J: Neuropathy after cyclophosphamide high dose chemotherapy in a Morbus Werlhof patient. Deutsche Med. Wochenschrift 2001;126(12):T17-T20. [German]

7. Könczöl F, Wiegand N, Nőt LG, Lőrinczy D. Examination of the cyclophosohamide-induced polyneuropathy on guinea pig sciatic nerve and gastrocnemius muscle with differential scanning calorimetry. J Thermal Anal Calorim. 2014;115:2239-43.

8. Farkas P, Könczöl F, Lőrinczy D. Examination of the peripheral nerve and muscle damage in cyclophosphamide monotherapy with DSC in animal models. J Thermal Anal Calorim. 2016;126:47-53.

9. Farkas P, Könczöl F, Lőrinczy D. Examination of the blood plasma and red blood cells in cyclophosphamide monotherapy with DSC in animal models. J Thermal Anal Calorim. 2017;127:1239-43.

10. Farkas P, Lőrinczy D. New possibilities of application of differential scanning calorimetry - new clinical diagnostic methods on the horizon? Temperature. 2017;4(2):120-2.

11. Lőrinczy D. Investigation of side effects in polyneuropathy on skeletal muscle by DSC caused by cyclophosphamide treatment. Eur Biophys J. 2019;48(Suppl. 1):S238.

12. Lőrinczy D. Cyclophosphamide treatment evoked side effects on skeletal muscle monitored by DSC. J Thermal Anal Calorim. 2020;142:1897-901.

13. Dergez T, Könczöl F, Farkas N, Belagyi J, Lőrinczy D. DSC study of glycerol-extracted muscle fibers in intermediate states of ATP hydrolysis. J Thermal Anal Calorim. 2005;80:445-9.

14. Dergez T, Lőrinczy D, Könczöl F, Farkas N, Belagyi J. Differenital scanning calorimetry study of glycerinated rabbit psoas muscle fibres in intermediate state of ATP hydrolysis. BMC Struct Biol. 2007;7:41-50.

15. Cossart P. Actin-based bacterial motility. Curr Opin Cell Biol. 1996;7:94-101.

16. Steinmetz MO, Stoffler D, Hoenger A, Bremer A, Aebi U. Actin: From cell biology to atomic detail. J Struct Biol. 1997;119:295-320.

17. Pollard TD, Blanchoin L, Mullins RD. Molecular mechanisms controlling actin filament dynamics in nonmuscle cells. Ann Rev Biophys Biomol Struc. 2000;29:545-76.

18. Pollard TD, Borisy GG. Cellular motility driven assembly and dissembly of actin filaments. Cell. 2003;112:453-65.
19. Carlier M-F, Le Clainche C, Wiesner S, Pantolini D. Actinbased motility: from molecules to movement. BioEssays. 2003;25:336-45.

20. Pantolini D, Le Clainche C, Carlier M-F. Mechanism of actinbased motility. Science. 2001;292:1502-6.

21. Hehnly H, Stamnes M. Regulating cytoskeleton-based vesicle motility. FEBS Lett. 2007;581:2112-8.

22. Sheterline P, Clayton J, Sparrow J. Actin Protein profile. 1995;2:1-103.

23. Feuer G, Molnár F, Pettko E, Straub FB. Studies on the composition and polymerization of actin. Hung Acta Physiol. 1948;1(4-5):150-63.

24. Pollard TD. Rate constants for the reactions of ATP- and ADP-actin with the ends of actin filaments. J Cell Biol. 1986; 103:2747-54.

25. Carlier M-F, Pantolini D. Direct Evidence for ADP-P $-\mathrm{F}-$ Actin as the Major Intermediate in ATP-Actin Polymerization. Rate of Dissociation of $\mathrm{P}_{\mathrm{i}}$ from Actin Filaments. Biochemistry 1986;25:7789-92.

26. Korn ED. Carlier M-F, Pantaloni D Actin polymerization and ATP hydrolysis. Science. 1987;238:638-44.

27. Carlier M-F. Role of nucleotide hydrolysis in the polymerization of actin and tubulin. Cell Biophys. 1988;12:105-17.

28. Carlier M-F, Pantolini D. Binding of phosphate to F-ADP-actin and role of F-ADP-P(i)-actin in ATP-actin polymerization. J Biol Chem. 1988;263:817-25.

29. Janmey PA, Hvidt S, Oster GF, Lamb J, Stossel TP, Hartwig JH. Effect of ATP on actin filament stiffness. Nature. 1990;347:95-9.

30. Pollard TD, Goldberg I, Schwarz WH. Nucleotide exchange, structure, and mechanical properties of filaments assembled from ATPactin and ADP-actin. J Biol Chem. 1992;267:20339-45.

31. CombeaU c, Carlier M-F. Probing the mechanism of ATP hydrolysis on F-actin using vanadate and the structural analogs of phosphate BeF-3 and A1F-4. J. Biol. Chem. 1988;263:17429-36.

32. Muhlrad A, Cheung P, Phan B.C, Miller C, Reisler E. Dynamic properties of actin. Structural changes induced by beryllium fluoride. J. Biol. Chem. 1994,269:11852-8.

33. Muhlrad A, Ringel I, Pavlov D, Peyser YM, Reisler E. Antagonistic effects of cofilin, beryllium fluoride complex, and phalloidin on subdomain 2 and nucleotide-binding cleft in F-actin. Biophys J. 2006;91:4490-9.

34. Drewes G, Faulstich H. Cooperative effects on filament stability in actin modified at the C-terminus by substitution or truncation. Eur J Biochem. 1993;212:247-53.

35. Orlova A, Prochniewicz E, Egelman EH. Structural Dynamics of F-Actin: II. Cooperativity in Structural Transitions. J. Mol. Biol. 1995;245:598-07.

36. Orlova A, Egelman EH. Cooperative rigor binding of myosin to actin is a function of F-actin structure. J Mol Biol. 1997;265:469-74.

37. Moracewska J. Structural determinants of cooperativity in actomyosin interactions. Acta Biochim Pol. 2002;49:805-12.

38. Egelman EH. A tale of two polymers: New insights into helical filaments. Nat Rev Mol Cell Biol. 2003;4:621-30.

39. Visegrády B, Lőrinczy D, Hild G, Somogyi B, Nyitrai M. The effect of phalloidin and jaspaklinolide on the flexibility and thermal stability of actin filaments. FEBS Lett. 2004;565:163-6.

40. Visegrády B, Lơrinczy D, Hild G, Somogyi B, Nyitrai M. A simple model for the cooperative stabilisation of actin filaments by phalloidin and jasplakinolide. FEBS Lett. 2005;579:6-10.

41. Spudich JA, Watt S. The regulation of rabbi tskeletal muscle contraction. I. Biochemical studies of the interaction of the tropomyosin-troponin complex with actin and the proteolytic fragments of myosin. J. Biol. Chem. 1971;246(15):4866-71. 
42. Lodish H, Berk A, Zipursky SL, et al. Molecular Cell Biology. 4th edition. New York: W. H. Freeman; 2000. Section 18.1, The Actin Cytoskeleton.

43. Tatunashvili LV, Privalov PL. Calorimetric investigation of G-actin denaturation. Biofizika. 1984;1984(29):583-5.

44. Bertazzon A, Tian GH, Lamblin A, Tsong TY. (1990) Enthalpic and entropic contributions to actin stability: calorimetry, circular dichroism, and fluorescence study and effects of calcium. Biochemistry. 1990;29:291-8.

45. Le Bihan T, Gicquaud C. Kinetic study of the thermal denaturation of Gactin using differential scanning calorimetry and intrinsic fluorescence spectroscopy. BBRC. 1993;194:1065-73.

46. Lő́rinczy D, Belágyi J. Scanning calorimetric and EPR studies on thermal stability of actin. Thermochimica Acta 1995. 259. 153-64.

47. Levitsky DI. Structural and functional studies of muscle proteins by using differential scanning calorimetry. In The Nature of Biological Systems as Revealed by Thermal Methods (Lőrinczy D, ed.) Kluwer, Dordrecht. 2004, pp. 127-58.

48. Orbán J, Pozsonyi K, Szarka K, Barkó Sz, Bódis E, Lőrinczy D. Thermal characterization of actin filaments prepared from
ADP-actin monomers. J. Thermal Anal. Calorimetry 2006; 84:619-23.

49. Levitsky DI, Pivovarova AV, Mikhailova VV, Nikolaeva OP. Thermal unfolding and aggregation of actin. Stabilization and destabilization of actin filaments. FEBS J. 2008;275:4280-95.

50. Kabsch W, Mannherz HG, Suck D, Pai EF, Holmes KC. Atomic structure of the actin: DNase I complex. Nature. 1990;347:37-44.

51. Kabsch W, Holmes KC. The actin fold. FASEB J. 1995;9:167-74.

52. Banga I, Szent-Györgyi A. Preparation and properties of myosin A and B. Stud. Inst. Med. Chem. Univ. Szeged 1941- 42a;I: 5-15.

53. Szent-Györgyi A. The contraction of myosin threads. Stud. Inst. Med. Chem. Univ. Szeged 1941- 42a;I:17-26.

54. Szent-Györgyi A. Discussion. Stud. Inst. Med. Chem. Univ. Szeged 1941- 42a;I: 67-71.

55. Manji H. Toxic neuropathy. Curr Opin Neurol. 2011;24:484-90.

Publisher's Note Springer Nature remains neutral with regard to jurisdictional claims in published maps and institutional affiliations. 